\title{
ART INTERVENTION IN THE SUB-URBAN AREA VISUAL CHARACTERISTIC
}

\author{
Adityo $^{1}$ \\ ${ }^{1}$ Department of Architecture, Universitas Atma Jaya Yogyakarta, Jl. Babarsari no.44, Yogyakarta, Indonesia \\ adityo@uajy.ac.id ${ }^{1}$
}

How to cite (in APA style):

Adityo (2019). Art Intervention In The Sub-Urban Area Visual Characteristic. Undagi: Jurnal Ilmiah Arsitektur. 7(2), pp.163-171.

\begin{abstract}
Indonesia Art Institute of Yogyakarta is one of well- known art college in Indonesia. This institution has graduated many Indonesian famous artists. Located at Sewon, Bantul, this institution has a significant effect on the suburban area development of the institution surrounding area. The art atmosphere of surrounding area shaped by Artactivities that happened there. Many formal or informal artspace also located there stimulate the activities to become intense and sustain. Beside that One thing that enriching the art atmosphere is mural drawing that done in private properties in the public spaces. The mural drawing spreading around the suburban area surrounding the college building. 20 mural has been recorded only in one village, and its enrich the visual aspect of the suburban area and beautifully blending to the suburban area. The mural draws also expresses a message for people who have seen it as a sightseeing object and makes the suburban area as a public artwork gallery. This research aims to know the factors how the mural drawing can be blend to the area and strengthen the place identity of the area by knowing the relationship between mural drawing and where it is made. Observation has been done in the sub-urban area surrounding the Indonesia art institute of Yogyakarta. The concept of the mural is contextual to the site. Its usually represent the social or environmental issue that happens there. The space and sensitivity of selection the mural drawing theme not only make the artwork blended naturally with the area but improve placeidentity of the area. Furthermore the phenomena have potential to be a theme of this suburban area development.
\end{abstract}

Keywords: art, mural, place-identity, sub-urban

\section{INTRODUCTION}

Yogyakarta is famous for its art and culture. An intense art activity occurs all yearlong such as art exhibition, cultural festival, and other art and cultural events. Some of the events, as it is an annual event like Artjog or biannual such as Jogja Biennale. Both of those events are an example of very well known nationally or even internationally. These art activities developed organically since there is nothing like an art center or any designated area to do so. Art happens all over the place. First, we have an art gallery or museum as a formal art space. The second one is informal art space where art filling and fitting in many spaces from the rural areas to undesignated spaces such as village fields and housing yards.

This kind of art behavior is adapted and becomes a characteristic of art in Yogyakarta. Ngayogjazz and Festival Kesenian Yogyakarta
(FKY) are one of the events to take this particular characteristic and turn it to trademark. The flexibility of place to support art activity blends with the local community and culture where the event takes place. (Sutopo, 2012) This

particular relation between art and place not only causing the better quality of local environmental infrastructure but also ameliorate culturally.

Yogyakarta Indonesian Art Institute (ISI Yogyakarta) is an art education institution that graduated to famous Indonesian artists. The existence of ISI Yogyakarta makes the influence of the art atmosphere around the campus area. There are art galleries, art spaces, artist studios located around ISI Yogyakarta, some of which are alumni of the campus who live in the area around the campus. That phenomena make the artistic atmosphere stronger. Physically the area around ISI Yogyakarta can be classified into suburban classification with the dominance of 
settlements arranged organically and mixed residential areas and productive land in one area. Another exciting thing from this area is the mixing of art objects with suburban areas. The suburban area does not only have an organic setting of settlement, productive area, natural area, and daily activities that are still strong with local value but also has a uniquely artistic atmosphere because of the art object that is spreading around the area.

Mural drawing is one form of art that blends in the region. In the area around ISI Yogyakarta there are many mural drawings drawn on walls in residential areas which are entirely private ownership. The existence of this mural drawing is the work of artists and art students individually or through art events. One of the art events that support the existence of this mural draw is Geneng street art project which has a mission to raise the name of Geneng village as a street art tourist attraction.

The existence of mural drawings usually becomes dominant in an area because it can be the center of attention. The mural drawing character, which has a variety of colors and attractive images makes mural drawing easy to identify and see. The dominance of mural drawings sometimes cannot blend with existing local characters so that it can reduce the character of an area. In the area around ISI Yogyakarta, the existence of mural drawing looks harmonious with the area and strengthen the character of the area, an artistic atmosphere with the existing local context. So how does the mural drawing blend with the character of the existing area to be interesting to see?

Mural drawing is a form of art that exists on architectural elements (walls and public spaces). It is necessary for architects, urban designers or tourist planners to pay attention to this element. So that in planning a mural area can be used as an element that helps visual arrangement of the area. The purpose of this study is to determine the factors that make mural drawings can be in harmony with their environment. With the harmony between the mural drawing and the place where the mural was drawn, making the mural is not only to decorate the walls, but also enhance the image of an area and can be part of the architectural elements of an area through visual aspects.

The mural drawing is one form of art that has a close relationship with architecture. The definition of a mural is a painting created to support architectural space. (Susanto, 2002) Wall as a media in making murals is an architectural element in a unit (building) even as a visual element in the public area if the wall that contains murals is on the exterior of the building and is in direct contact with public space. According to history, murals as wall decorations have existed from prehistoric times. The mural can be seen from the paintings on the walls of the cave to the baroque catholic church building, which is on the roof or the dome. Murals do not only stand alone as objects of art. For the artist, there are messages to be conveyed through the mural. There is a message by utilizing the mural drawings for portraying the conditions around them, such as for aesthetic purposes, to voice social and cultural conditions or other issues.

The mural does not stand alone without the presence of thousands of meanings. Humans are subjects that are bound by culture, so communication is needed with other subjects with a medium or language. Artworks as an expression of human feelings and emotions that can be translated into art, especially mural art. With a mural, someone can pour his expression to convey a message to the entire community or government in the form of visuals or images, in the social environment. (Dharsono Sony, 2004)

\section{METHODOLOGY}

The method used in this study is a visual survey with photography to record mural drawings that exist in the area around ISI Yogyakarta. Observations were made to see the physical settings The condition of the area where the mural was made. The data is recorded to see the relationship between mural drawings and their environment. The recording of the image is then plotted into the base map of the area that was made before. In general, the existence of mural drawings is spread evenly around the ISI Yogyakarta campus. However, the focus of the conservation and social survey 
was conducted in the eastern region bordering ISI Yogyakarta, namely in the geneng village

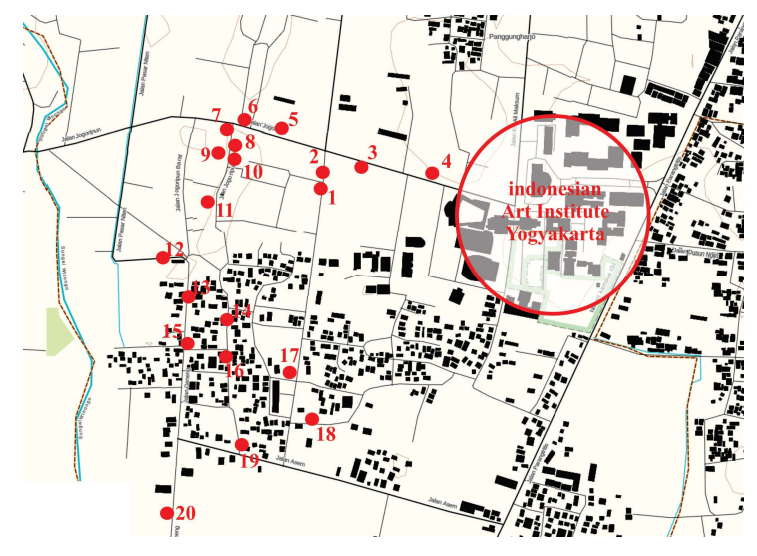

Figure 1. Mural Drawing Mapping (Source: author)

Interviews with art practitioners and the public in the selected area were carried out in the research process. The data obtained will be analyzed qualitatively. The analysis is carried out by understanding and compiling data between recorded observations and documentation and the results of interviews that have been collected, then systematically arranged so that conclusions can be drawn clearly.

\section{RESULTS AND DISCUSSION}

In the Geneng village and its surrounding area, mural drawings mostly found in accessible areas. It can be seen that all mural drawings are on the side of the village road and the kampong alley. The appearance of murals in the circulation area of the community makes the mural more exposed because people are passing by and naturally inviting people to look at the drawing. The area around the mural drawing is mostly located in densely populated settlements, in the kampong settlement. Many kinds of mural images making the village more attractive. The choice of the theme of mural drawing becomes very important so that later the mural drawing will be in harmony with the environment. The condition of the village that blends with the productive area makes the paddy field area also gets a mural drawing intervention. The existence of mural drawings that have agricultural themes in paddy fields provide accents of art and make the area more attractive.

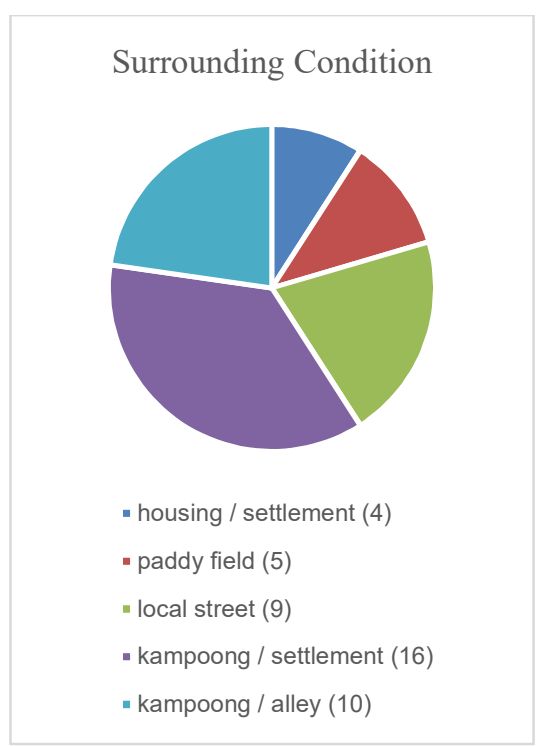

Figure 2. surrounding condition identification chart

(Source: author).

The Mural Drawing theme in the Geneng village and its surrounding is divided into ten themes. social and environmental themes become the most widely used themes. Social themes revolve around social life between humans and manners (table 1 number 6,7,11,13). Diverse suburban environmental conditions are very compatible with social themes. In the context of art, murals have been widely used throughout the history of human life as a medium to express social conditions, beliefs, as well as those related to politics and rebellion. All expressions are deliberately shown to appear before the public. The mural, which was made as a form of criticism and resistance to government policies, was considered more effective as a two-way communication medium that is, visual-verbal to the public. (Iswandi, 2016). The message conveyed is used as a reminder to the community to keep cooperation and respect, among others. This is still a characteristic of suburban and rural communities. The social theme is then connected to the environmental theme which tells the relationship between humans and the surrounding environment and nature in general (table 1 numbers $1,3,10,12,14$.). The theme of the environment 
shrinks to the theme of agriculture contained in the existing mural image. Table 1 numbers 1 , $10,12,15,14$.). Mural drawing with the theme of agriculture is in a location close to rice fields and villages, the majority of which work as farmers. From the selection of themes, there is a relationship between the mural image and where the picture was made. Themes that are close to the condition of the community and the surrounding environment make mural drawings in harmony with the place where they were made. Themes that have an imaginative character from the creator of the artist add to the diversity of the murals that exist in the region.

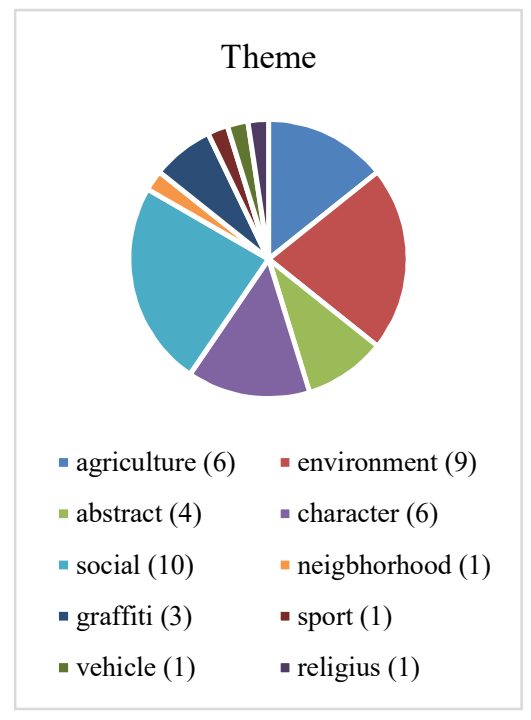

Figure 3. Theme Identification chart (Source: author).

The location of mural drawings made in this area is mostly on the walls of private houses. This proves the interaction between residents and the artists who made the pictures. This interaction provides collaboration results in mural drawing execution from determining the location of the mural drawing and the theme to be used. Negotiations of Space and wall area for mural drawings determined together and not only from one side. From interviews conducted with the artists, found that there was citizen participation in the making of murals, specifically in determining the fields and proposed themes to be used. Locations for making mural drawings other than private house walls are residential walls, local store walls, and office building walls (in a small portion).

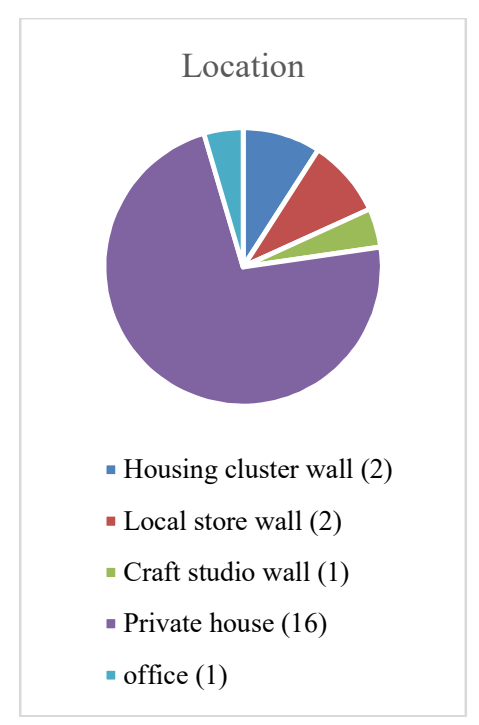

Figure 4. location identification chart (Source: author).

Visual Characteristics of mural drawings mostly contrast with the environment. It can be seen from Striking dan different colors from the surrounding environment. With the selection of striking colors makes the mural drawing more exposed and easy to see. It is paying attention of people who pass through it. The selection of creative and imaginative object images makes the mural stand out from the environment.

On the other hand, the thing that makes murals can be integrated with the surrounding environment is the selection of scale and proportion of mural drawings to the surrounding environment. Placement on the wall with a size that adjusts to the scale of elements of the environment around it makes the mural look attractive. The choice of size of objects in mural drawings can be treated well by the artists.

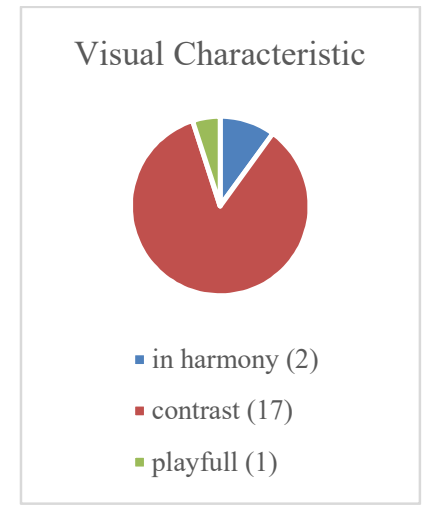

Figure 5. visual identification chart (Source: author). 
Tabel 1. Mural drawing theme compatibility breakdown

\begin{tabular}{|c|c|c|c|c|c|}
\hline No. & Mural Drawing & Theme & position & $\begin{array}{c}\text { Surrounding } \\
\text { condition }\end{array}$ & $\begin{array}{c}\text { Visual } \\
\text { characteristic }\end{array}$ \\
\hline 1 & & $\begin{array}{l}\text { - Agriculture } \\
\text { - Environme } \\
\text { nt }\end{array}$ & $\begin{array}{l}\text { - } \begin{array}{l}\text { Housing } \\
\text { cluster } \\
\text { wall }\end{array} \\
\text { a }\end{array}$ & $\begin{array}{ll}\text { - } & \text { Housing/set } \\
\text { tlement } \\
\text { - } & \text { Paddy field } \\
\text { - } & \end{array}$ & 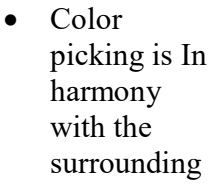 \\
\hline 2 & & $\begin{array}{l}\text { - Abstract } \\
\text { - Character } \\
\text { - mechanic }\end{array}$ & 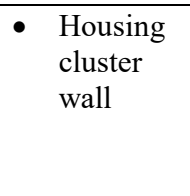 & $\begin{array}{ll}\text { - } & \text { Housing/set } \\
\text { tlement } \\
\text { - } & \text { Paddy field } \\
\text { - } & \text { Local street }\end{array}$ & $\begin{array}{l}\text { - Have a } \\
\text { contrast } \\
\text { colors with } \\
\text { the } \\
\text { surrounding }\end{array}$ \\
\hline 3 & & $\begin{array}{l}\text { - Social } \\
\text { - Environme } \\
\text { nt }\end{array}$ & $\begin{array}{l}\text { - } \begin{array}{l}\text { Local } \\
\text { store wall }\end{array} \\
\end{array}$ & $\begin{array}{ll}\text { - } & \text { Housing/set } \\
\text { tlement } \\
\text { - } & \text { Paddy field } \\
\text { - } & \text { Local street }\end{array}$ & $\begin{array}{l}\text { Have a } \\
\text { contrast } \\
\text { colors with } \\
\text { the } \\
\text { surrounding }\end{array}$ \\
\hline 4 & & $\begin{array}{l}\text { - Social } \\
\text { - Environme } \\
\text { nt }\end{array}$ & $\begin{array}{l}\text { - } \begin{array}{l}\text { Local } \\
\text { store wall }\end{array} \\
\end{array}$ & 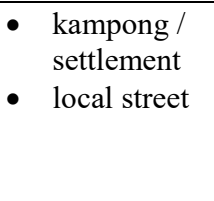 & $\begin{array}{l}\text { Have a } \\
\text { contrast } \\
\text { colors with } \\
\text { the } \\
\text { surrounding }\end{array}$ \\
\hline 5 & & $\begin{array}{l}\text { - Human } \\
\text { - Abstract } \\
\text { - Social }\end{array}$ & $\begin{array}{ll}\text { - } & \text { Craft } \\
& \text { studio } \\
\text { wall }\end{array}$ & $\begin{array}{l}\text { - Housing/set } \\
\text { tlement } \\
\text { - Local street }\end{array}$ & 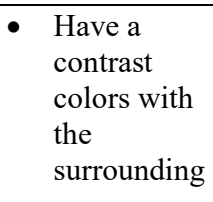 \\
\hline 6 & & $\begin{array}{l}\text { - Social } \\
\text { - neighborho } \\
\text { od }\end{array}$ & $\begin{array}{ll}\text { - } & \begin{array}{l}\text { Private } \\
\text { house }\end{array}\end{array}$ & $\begin{array}{ll}\text { - } & \text { kampong / } \\
\text { settlement } \\
\text { - } \\
\text { kampong } \\
\text { alley }\end{array}$ & $\begin{array}{l}\text { Have a } \\
\text { contrast } \\
\text { colors with } \\
\text { the } \\
\text { surrounding }\end{array}$ \\
\hline
\end{tabular}




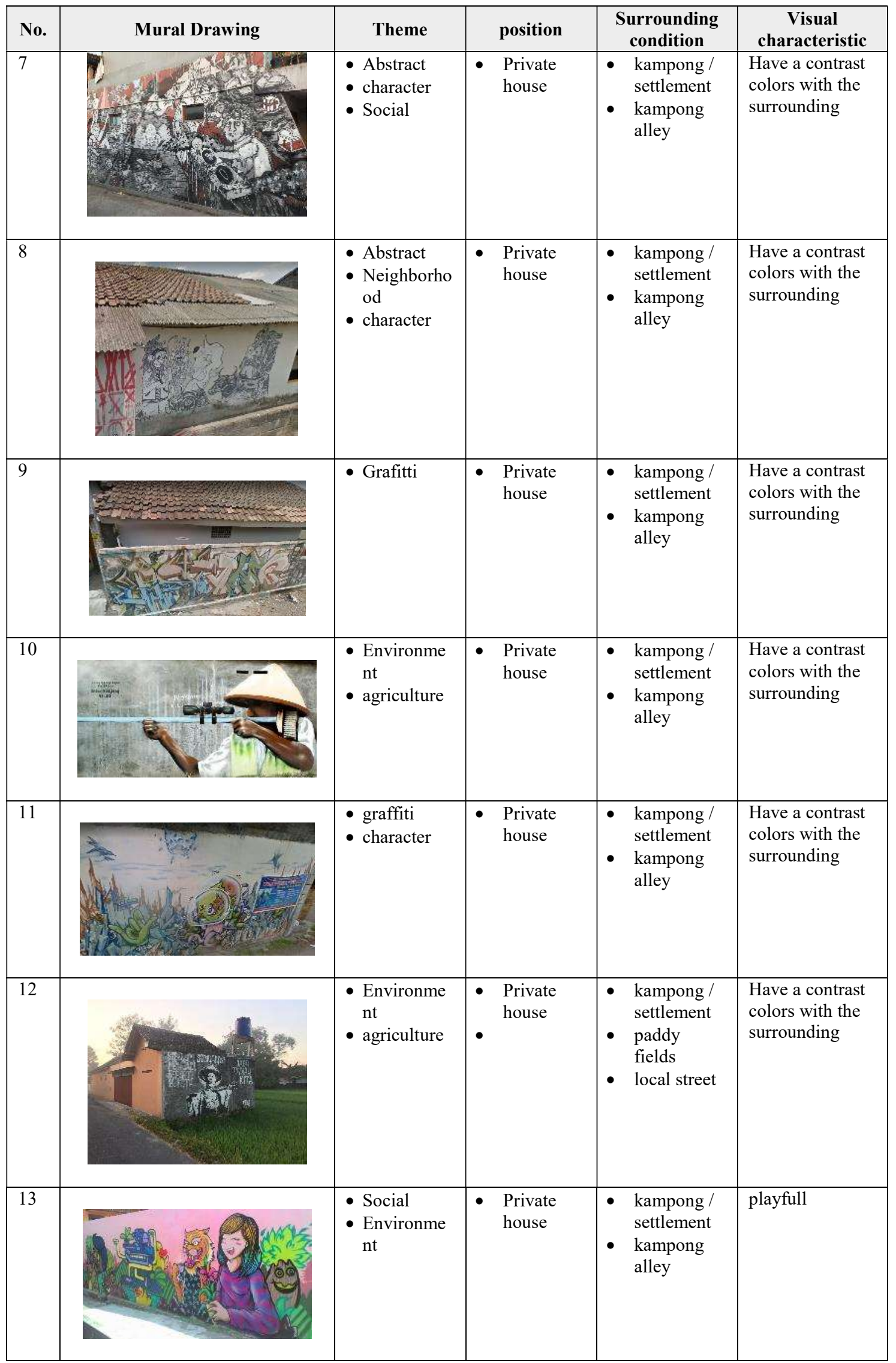




\begin{tabular}{|c|c|c|c|c|c|}
\hline No. & Mural Drawing & Theme & position & $\begin{array}{c}\text { Surrounding } \\
\text { condition }\end{array}$ & $\begin{array}{c}\text { Visual } \\
\text { characteristic }\end{array}$ \\
\hline 14 & & $\begin{array}{l}\text { - Social } \\
\text { - Environme } \\
\text { nt } \\
\text { - agriculture }\end{array}$ & $\begin{array}{ll}\text { - } & \text { Private } \\
\text { house }\end{array}$ & $\begin{array}{ll}\text { - } & \text { kampong / } \\
\text { settlement } \\
\text { - } \\
\text { kampong } \\
\text { alley }\end{array}$ & $\begin{array}{l}\text { Have a contrast } \\
\text { colors with the } \\
\text { surrounding }\end{array}$ \\
\hline 15 & & $\begin{array}{l}\text { - Social } \\
\text { - Environme } \\
\text { nt } \\
\text { - agriculture }\end{array}$ & $\begin{array}{ll}- & \text { Private } \\
\text { house }\end{array}$ & 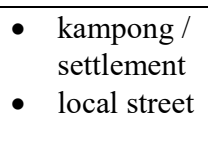 & $\begin{array}{l}\text { Have a contrast } \\
\text { colors with the } \\
\text { surrounding }\end{array}$ \\
\hline 16 & & $\begin{array}{l}\text { - Social } \\
\text { - sport }\end{array}$ & $\begin{array}{ll}\text { - } & \text { Private } \\
\text { house }\end{array}$ & $\begin{array}{ll}\text { - } & \text { kampong / } \\
\text { settlement } \\
\text { - } \\
\text { kampong } \\
\text { alley }\end{array}$ & $\begin{array}{l}\text { Have a contrast } \\
\text { colors with the } \\
\text { surrounding }\end{array}$ \\
\hline 17 & & $\begin{array}{l}\text { - graffiti } \\
\text { - vehicle }\end{array}$ & - office & $\begin{array}{ll}\text { - } & \text { kampong / } \\
\text { settlement } \\
\text { - } & \text { local street }\end{array}$ & $\begin{array}{l}\text { Have a contrast } \\
\text { colors with the } \\
\text { surrounding }\end{array}$ \\
\hline 18 & & - character & $\begin{array}{l}\text { Private } \\
\text { house }\end{array}$ & $\begin{array}{ll}\text { - } & \text { kampong / } \\
& \text { settlement } \\
\text { - } & \text { local street }\end{array}$ & $\begin{array}{l}\text { Color picking is } \\
\text { In harmony with } \\
\text { the surrounding }\end{array}$ \\
\hline 19 & & $\begin{array}{l}\text { - Social } \\
\text { - religious }\end{array}$ & $\begin{array}{l}\text { - } \begin{array}{l}\text { Private } \\
\text { house }\end{array}\end{array}$ & $\begin{array}{ll}\text { - } & \text { kampong / } \\
\text { settlement } \\
\text { - } \\
\text { kampong } \\
\text { alley }\end{array}$ & $\begin{array}{l}\text { Have a contrast } \\
\text { colors with the } \\
\text { surrounding }\end{array}$ \\
\hline
\end{tabular}




\begin{tabular}{|c|c|c|c|c|c|}
\hline No. & Mural Drawing & Theme & position & $\begin{array}{l}\text { Surrounding } \\
\text { condition }\end{array}$ & $\begin{array}{c}\text { Visual } \\
\text { characteristic }\end{array}$ \\
\hline 20 & 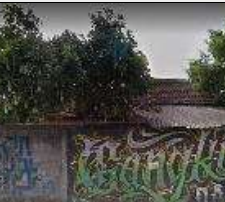 & $\begin{array}{l}\text { graffiti } \\
\text { agriculture } \\
\text { environmen } \\
t\end{array}$ & $\begin{array}{l}\text { Private } \\
\text { house }\end{array}$ & $\begin{array}{ll}\text { - } & \text { kampong / } \\
& \text { settlement } \\
\text { - } & \text { local street } \\
\text { - } & \text { paddy field }\end{array}$ & $\begin{array}{l}\text { Have a contrast } \\
\text { colors with the } \\
\text { surrounding }\end{array}$ \\
\hline
\end{tabular}

(Source: author)

From the several things observed in the existence of mural drawings in the Geneng village and its surrounding, it is not only as an expressive action or improvisation of the surrounding conditions. There is a dynamic in the manufacturing process that makes mural drawing has its value of existence. Seeing the harmonious relationship between mural drawing and its location cannot be separated from the actors and interactions that occur between them. In this case, it is the street artist and the property owner where the mural will be drawn.

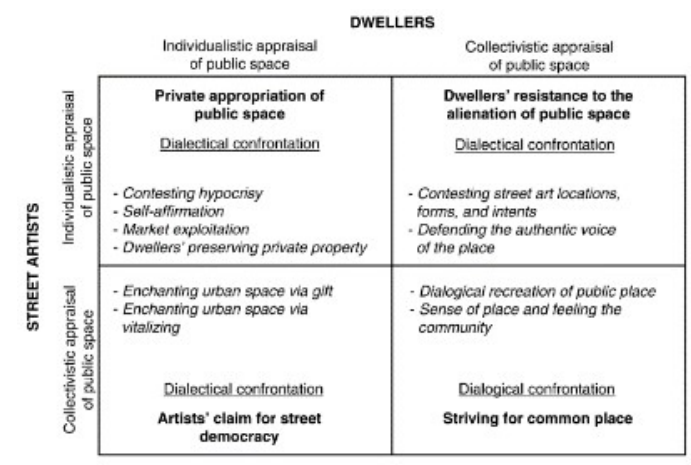

Figure 6. consumption ideologies of public space (Source:Visconti et al., 2014).

The ideology in the consumption of public space is divided into four based on the degree of individual and collective viewpoints of consumers assessment, namely in this context is artists and private property owners. The model can assess the value of a mural drawing (street art) in public space based on conditions in the area. Based on the analysis conducted, the dynamics of mural drawing making process starting from the theme, choosing the location of the mural, the condition of the surrounding environment and its visual characteristics are the result of interaction between artists and the surrounding community. By using the ideology of public space consumption model. (Visconti et al., 2014) It can be seen that the existence of mural drawings can have value to the environment if the planning can be done collectively by the stakeholders. The difference in perspective in the consumption of public space, the stresses that occur in cases of making murals can be suppressed with the spirit of togetherness formed from these interactions.

\section{CONCLUSION}

Harmony between Mural drawing and the environment can occur if the planning and implementation process still considers the values contained in an environment. Furthermore the selection of themes, locations, and attention to the environment must be discussed by the artists and people in the region. Moreover supported by the creative process in its implementation by the artists. The existence of mural drawings located in suburbs that have organic and diverse conditions with an agrarian style and dominant villages make the area attractive. In the future, this matter should get the attention of various parties because it has the potential as a sight-seeing tourist destination and art destinations in the Yogyakarta area. Regional planners and urban designers in the future can become involved in seeing mural drawings as elements in an area that can be utilized following their designation and provide their value to a visual characteristic of the area.

\section{REFERENCES}

Dharsono Sony, K. (2004) Seni Rupa Modern. Bandung: Rekayasa Sains. 
Iswandi, H. (2016) 'SENI MURAL SEBAGAI UNSUR POLITIK DALAM', Besaung , jurnal seni desain dan budaya, 1(1), pp. 914.

Susanto, M. (2002) Diksi rupa: Kumpulan Istilah Seni Rupa. Yogyakarta: Kanisius.

Sutopo, O. R. (2012) 'Transformasi Jazz Yogyakarta: Dari Hibriditas menjadi Komoditas', jurnal sosiologi masyarakat, 17(1), pp. 65-84.

Visconti, L. M. et al. (2014) 'Street Art, Sweet Art? Reclaiming the "Public" in Public Place', Chicago Journals, 37(3), pp. 511529. doi: 10.1086/652731. 